\title{
Insights from a Calibrated Optimization Model for Irrigated Agriculture under Drought in an Irrigation District on the Central Mexican High Plains
}

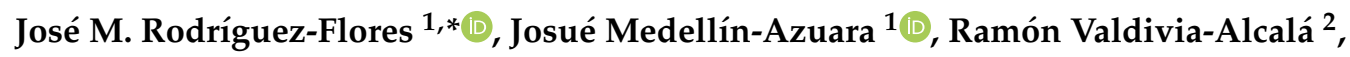 \\ Oscar A. Arana-Coronado ${ }^{3}$ and Roberto C. García-Sánchez ${ }^{3}$ \\ 1 Department of Civil and Environmental Engineering, University of California, Merced, 5200 Lake Road, \\ Merced, CA 95340, USA; jmedellin-azuara@ucmerced.edu \\ 2 División de Ciencias Económico-Administrativas, Universidad Autónoma Chapingo. Km 38.5 carretera \\ México-Texcoco, Texcoco de Mora, Estado de México 56230, Mexico; ramvaldi@gmail.com \\ 3 Economía, Colegio de Postgraduados, Campus Montecillo. Carretera México-Texcoco. Km. 36.5. Montecillo, \\ Estado de México 56230, Mexico; aranaosc@colpos.mx (O.A.A.-C.); rcgarcia@colpos.mx (R.C.G.-S.) \\ * Correspondence: joss.rdgz@gmail.com; Tel.: +52-55-69-89-45-93
}

Received: 21 January 2019; Accepted: 17 April 2019; Published: 24 April 2019

\begin{abstract}
An economic assessment of the value of agricultural water was conducted at the subdistrict (module) level within the Alto Rio Lerma Irrigation District 011 in Guanajuato, Mexico. The assessment employed positive mathematical programming (PMP), a deductive valuation methodology, which self-calibrates to baseline production input use. Production and water use values for the 2016-2017 agricultural year, and the averages of the 2014 to 2017 agricultural years for yields, agricultural commodity prices, and production costs were employed disaggregated per irrigation module. Results indicate that the economic value of water is 1.8 to 4.7 times higher than the rate currently paid by users, about US\$7.89 $\mathrm{dam}^{-3}$ (cubic decameters). The differences among the rate and shadow prices could create a pricing water policy focused on water conservation and its efficient use. This work also conducts an assessment of a formal water market in the irrigation district as way to achieve economically efficient water allocations and reduce the potential economic impacts of water shortage during droughts. Modeling results show that an active water market would allow the irrigation district to adapt to scarcer water conditions by shifting cropping patterns and trading water among subdistricts, by reducing loss in net income at the irrigation district. A successful implementation of this system would be feasible, provided that the irrigation modules are able to import and export water, under water scarcity scenarios considered for the water market model. Potential distributional effects and policy insights from this assessment are discussed.
\end{abstract}

Keywords: positive mathematical programming; irrigation water; drought; water markets; Guanajuato; Mexico

\section{Introduction}

In recent years, water scarcity has increased awareness about the water-related challenges faced by the Mexican economic sectors, particularly irrigated agriculture. Agriculture is often affected, as it is the sector with the highest consumptive water use both from surface and groundwater sources in Mexico. According to the National Water Commission (CONAGUA), the agricultural sector uses roughly $76.3 \%$ of the available fresh water for human uses in Mexico [1]. In addition, irrigated agriculture faces other problems in its vulnerability to the effects of climate change, and to political, technological, and economic challenges. However, there are ways in which agriculture can adapt to availability challenges and achieve an economically efficient water resource allocation. According to 
Scheierling et al. [2], water is used in an economically efficient manner when the net economic benefit of its use is maximized.

Faced with this problem, policies must be made that facilitate an efficient water management. Developing policies from the supply side cannot sustain an increasing demand; hence, demand side management is preferred. The Food and Agriculture Organization of the United Nations (FAO) [3] defines water demand management as involving those actions that control demand, using as a tool the allocation of water resources within each sector and among the different sectors.

The economic value of water in irrigated agriculture is defined as the marginal value added if one extra volumetric unit was supplied [4]. Having information about the economic value of water in irrigated agriculture allows policy makers, investors, and government agencies to select the best decision for financing and distributing the resource, allocating it to wherever it obtains the greatest economic benefit and prevents overexploitation [3]. Using the economic value of water could facilitate the design of a pricing policy framework to promote efficient water allocation among users, as has been researched and applied in various countries [5,6]. In the EU and in Mexico, water pricing has been used as an incentive for water conservation and its efficient use in irrigation; however, other elements such as the regulatory framework, supply systems, and policies must be considered, as explained by Garrido and Calatrava [7]. The economic value of water also provides an indication about water scarcity that could not be known in the absence of formal markets.

Policies on water demand management include the creation of water markets, which have been developed formally in different countries, and which have proved to be a successful mechanism to optimize its use and face of drought scenarios, as explained by Grafton et al. [8]. Water irrigation markets facilitate the water rights transfer among farmers, from low value to high value uses, with an institutional support and a legal and regulatory framework.

Several authors have researched about the performance of water markets in various countries: In Spain, Palomo-Hierro [9] concluded that water markets have had shortcomings in their application due to barriers and restrictions; however, water markets have been seen as useful tools in drought periods. In California, water markets have had an important role during droughts within the last decades. Water markets have assisted agriculture in reducing economic losses and have led to an efficient allocation across the state, despite the fact that water markets are limited by physical, ecological, and political constraints [10]. In Australia, the Murray-Darling Basin is the most important water market in the country; it is a good representation of how water markets have evolved politically and socially, in order to have an active market [11].

Models are used to abstract and simplify phenomena from reality [12]. Modeling methods, either inductive or deductive [13], have proven to be a useful tool for estimating the economic value of water and its demand for irrigation use, as indicated by Tsur [14], as well as for assessing water allocation policies [15]. The use of inductive techniques including statistical methods, e.g., econometrics, applied for irrigation water value and water derived demand in agriculture, have been used in different countries, with insights for water policy applications, as can be seen in Zhu et al., Mesa-Jurado et al., and Sun et al. [16-18].

Deductive techniques, such as mathematical programming models, use a theoretical basis for their formulation and allow including technical, environmental, and economic variables, as indicated by Booker et al. [19]. These models use theoretical specification of agricultural production; hence, physical resource-limited scenarios can be formulated in order to evaluate policies. Linear programming (LP), non-linear programming (NLP), general equilibrium models (GEM), and positive mathematical programming (PMP) are the most common among programming methods applied to water valuation and water allocation optimization, also called Hydro-economic models. Theory, mathematical formulation, and several applications of hydro-economic models were reviewed by Harou et al. [20].

Hydro-economic models have been applied at various spatial and temporal scales. Models can be flexible in the use of data from either a single producer or an aggregate of multiple producers, which enable the formulation of these models with different scales [13]. In the case of this research, 
an irrigation district was modeled with data disaggregated by irrigation subdistrict also known as module. This enabled the analysis of drought impacts on the irrigation modules and the aggregation of them within the irrigation district. In addition, the model can be used to evaluate the interactions among irrigation modules in an efficient water market.

Models for water allocation analysis have had several applications. Singh et al. [21] made an extensive literature review of different water allocation optimization models, using different methodologies, such as linear programming, non-linear programming, among others. These models were based on maximization of net income, minimization of waterlogging, or minimization of groundwater depletion. Wang et al. [22] developed a water allocation model, which consisted of the economic, social, and environmental maximization in the objective function, subject to local resources and socio-economic conditions in the Heihe River Basin of China. Erfani et al. [23] designed an optimization model to assess the economic and hydrologic outcome, within a weekly water market among public water supply, agriculture, energy, and industrial use, including transaction costs of the market.

Other application for an irrigation water market evaluation and derived demand curves estimation were applied by Pujol et al. [24], using a multicriteria decision model. Calatrava and Garrido [25] modeled a water market to reduce the exposure of farmers to risk associated with uncertain supply. Grafton et al. [26] implemented an optimal dynamic water allocation model for environmental release and irrigation allocation, with different variables, such as weather and storage.

In this regard, the above research shows the advantages in the use of hydro-economic models for economic valuation of water and for modeling water allocation policies, particularly when the objective of the model is the maximization of the net income in agriculture. In addition, the commented research proved the suitability of mathematical programming models in the use of limited data. The present study contributes to the literature of hydro-economic models, using positive mathematical programming with a calibrated non-linear model. A base-year dataset in the use of inputs and the mean of three years of costs and prices were used, described in Section 3.2. This study shows the derived demand curves of water, per irrigation module, using a calibrated model, which enabled us to calculate the different shadow prices at different water availabilities; furthermore, an efficient water market as a policy to reduce the net income losses due to scarcity was analyzed. The results can be used for policy analysis in the efficient use of water in agriculture, at irrigation module and irrigation district level.

\section{Study Area Characterization}

The study area for this research was Alto Rio Lerma Irrigation District 011 (ID011), located in the central Mexican High Plains on the state of Guanajuato, within the Lerma-Chapala Basin. ID011 is the largest irrigation district in the basin and has the highest water demand. This district has a total of 111,242 hectares (ha), of which 110,299 ha are irrigated and belong to 26,611 users. Within the Irrigation District 011, there are 11 modules or water user associations. For the valuation and assessment of the water market, the 11 irrigation modules were considered separate spatial analysis units and representative producers (Figure 1).

The water sources for the Alto Rio Lerma Irrigation District are surface water and groundwater obtained as a concession basis from government and private wells, registered in the Public Water Rights Registry (REPDA) [27]. The surface water supply sources are: The Tepuxtepec hydro-electric Dam; the Solis Dam, which receives approximately $90 \%$ of its water from the Tepuxtepec Dam and Lerma River runoff; the Yuriria Lagoon, which serves as the system's regulating reservoir, and the La Purísima Dam, located in the northwest region of the district.

Historically, the region has been plagued by drought; the most recent drought occurred in 2011 and affected central and northern Mexico. It is considered the worst drought in the last seven decades and had a strong negative impact on agricultural production. The 2011 drought led to actions intended 
to mitigate future drought impacts and regularize the water allocation; the water delivery for the next year to the irrigation district was just $50 \%$ of 2016 .

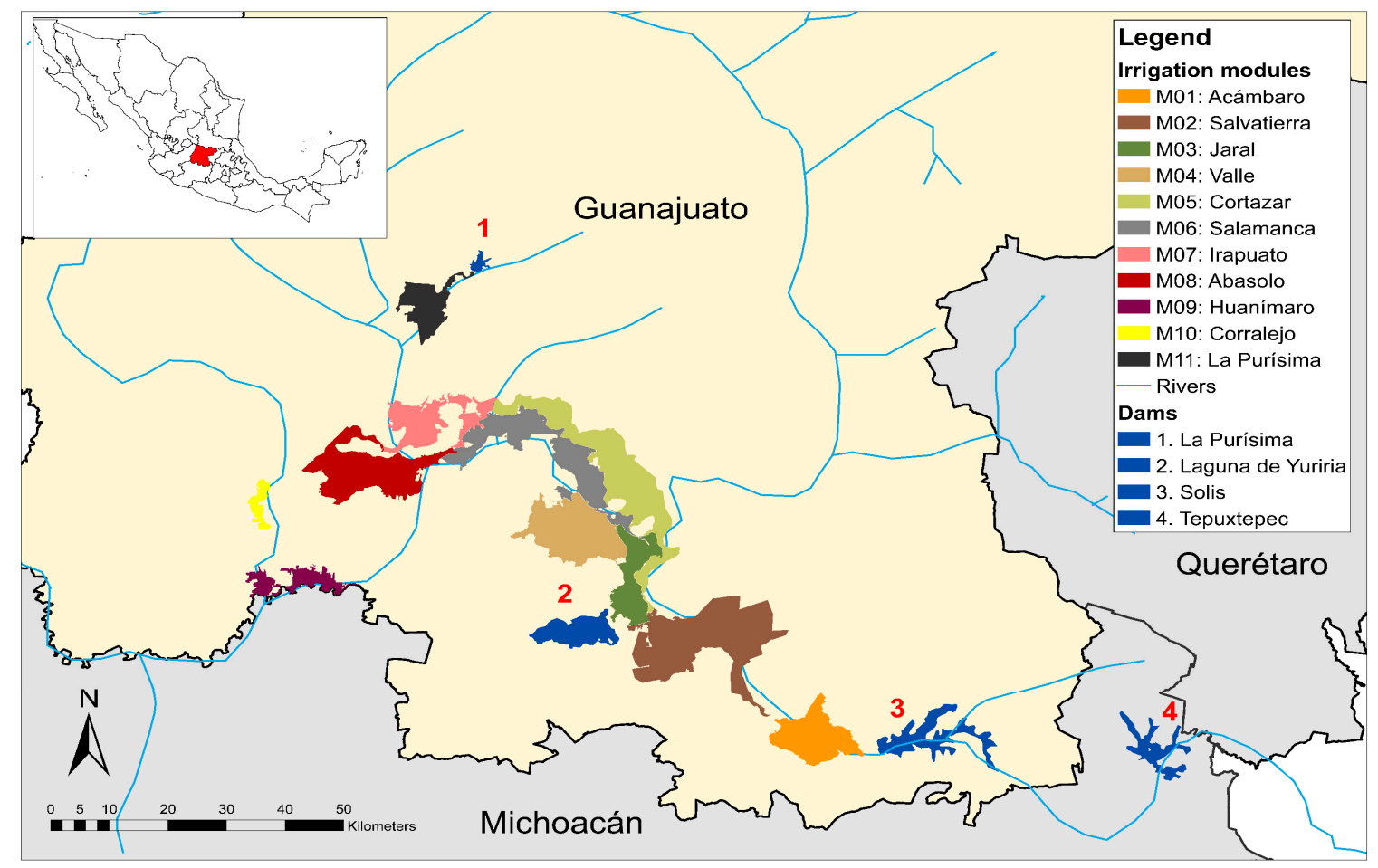

Figure 1. Irrigation District 011 Alto Rio Lerma in the state of Guanajuato, México.

At the present time, the basin water availability is limited, due to increasing urban, agriculture, and industry demand. In addition, the aquifers are overdraft [28], and the surface water streams and reservoirs have serious pollution problems [29,30]. Therefore, granting more surface or groundwater use rights would not only affect water uses downstream, but will also put the region's future development at risk.

The above conditions of the Lerma-Chapala Basin changed the legal water titles regularization [31]. The Basin is currently under ban from groundwater exploitation beyond the quantity assigned by water rights, banning the construction of new wells and not granting new water use rights titles. The water commission can only give those titles which have expired or renewing them. Each title has an average period of 10 years, and up to 50 years for surface water and groundwater. The above situation has resulted in a serious conflict in terms of meeting the demand of different economic agents [32,33], and it has also triggered an illegal water market as has been seen in Guanajuato and other states of Mexico [34].

Future water scarcity scenarios present major challenges, which may be exacerbated under warmer and drier long-term conditions. SAGARPA-FAO [35] studied the vulnerability of Mexico's agricultural regions to the effects of climate change, forecasting an increase in temperature and a reduction in precipitation, as well as more frequent droughts, particularly in the north and north-central regions of the country where the basin under study is located. The Ecology Institute of the State of Guanajuato [36] expects temperature increases of up to $3.0^{\circ} \mathrm{C}$ in the state over the next decades, which will cause greater evaporation and a negative effect on the rainfall-runoff process, which would reduce Lerma River streamflow and water storage in the water supply dams for the Irrigation District 011. Water resources (surface and groundwater) will be reduced throughout the state, and with the increased water demand for urban, industrial, and agricultural uses, the existing gap between supply and demand is expected to increase. Specifically, for agricultural use demand, extraction from wells is expected to increase between $30 \%$ and $80 \%$ by 2030 , and from surface sources by up to $10 \%$ over the same period. 
As discussed earlier, water markets have the potential to reallocate water at the subdistrict and district level in such a way that the economic cost of water shortages is minimized. The 2016 National Water Law [37], through a water market, allows economic agents to transfer their water use rights, fully or partially, among agriculture, urban, and industry users, as stipulated in Articles 33 to 37, provided that the Water Law, regulations, and the terms of use of each basin are under compliance. Transfers can only take place within the confines of the boundaries of aquifers and river basins, delimited by CONAGUA. Contrary to other countries that have different water allocation regimes, such as leasing, transferring, and trading explained and summarized by the OECD [38], in México the only legal allocation regime is transferring water rights through water markets.

Different researchers have addressed the advantages and disadvantages of a water market policy within the Lerma-Chapala basin. Pérez et al. [39] have studied the viability of creating this market, considering the institutional characteristics within the Lerma-Chapala Basin, as a mechanism to avoid overexploitation of the resource and as a mechanism to achieve a sustainable use of the water. Hoogesteger and Wester [40] have analyzed its viability as a policy in the State of Guanajuato to avoid overexploitation of aquifers, which has been incentivized by the highly subsidized electricity rate, particularly for agricultural use by the "Tarifa 9" of the Federal Electricity Commission (CFE) [41], demonstrated by Scott and Shah [42]. A legal and regularized water market is the only viable policy to acquire water titles, which could achieve a sustainable use of the water and be flexible towards future scarcity scenarios.

\section{Methodology}

There are various methodologies that allow estimating the economic value of water; two methodological approaches have been mainly used for the economic valuation of water when used in agriculture: Inductive and deductive [43]. Inductive methods, such as econometric models, are parametric approaches that infer generalizations based on individual observations; on the other hand, deductive methods, including mathematical programming (MP), use the principle of optimization, based on general premises that result in particular conclusions [13].

One advantage that deductive methods have over inductive methods is that they do not need large databases for their validation and they also provide a better economic value estimation. The above can be seen in Florencio-Cruz et al. [44], who used a linear programming model to calculate the marginal productivity of water in Irrigation District 011, by limiting resources: Land, labor, agricultural machinery, and water (surface and groundwater). Their results were marginal values for the two water resource sources, in every month of the base agricultural year (1998-1999), with marginal values ranging between $\$ 0.54$ and $\$ 2.28 \mathrm{MXN}$ pesos (US $\$ 0.03$ and US $\$ 0.12$ ) per cubic meter.

The difference in shadow prices depends on the crop mix in a region and the water conditions. Because groundwater is often allocated for higher-value crops, it will have a higher marginal value. These authors concluded that in all cases, the shadow price is higher than the rate paid by producers, hence a rate increase would be a good instrument to improve water use efficiency. Notwithstanding, this research was applied at the same Irrigation District, the use of linear programming methods have showed limitations compared to PMP [12]. Aggregated data of the Irrigation District were used, without module distinction.

Research literature on modeling water value states that the fitting of mathematical programming models can be improved through calibration [45]. A calibration technique that has been specifically developed for economic research on agricultural water use and for analysis of water allocation policies is positive mathematical programming, which has been widely developed since it was formalized by Howitt [46].

Among the virtues of PMP is that it relaxes some linear programming assumptions, since it adds flexibility in the use of factors and in the behavior of costs, which are precisely calibrated to the observed production values. This can be seen in Medellín-Azuara et al. [47], that employed a PMP approach to estimate the economic value of water for agricultural use and its derived demand 
in three regions of Baja California. In order to calibrate the model, their base dataset included four productions namely, water, land, labor, and other supplies for the 2004-2005 base agricultural year. The final model they used a quadratic cost function and a constant elasticity of substitution production function. The estimated water marginal values range from 76 to 126 dollars per thousand cubic meters, and demand curves with average elasticities between -0.66 and -0.31 , depending on each region.

As mentioned above, the objective of water management within an agricultural region is to maximize the total net benefit of its use in production. In this research, the area of interest is an irrigation district composed of 11 irrigation modules (water user associations). The model seeks to maximize the total net economic returns to land and management at the district level, which is also the sum of the corresponding net economic return in each module. When water is used in agricultural production, it is considered an intermediate good because it is an input in a multistage production process; therefore, its demand is referred to as a derived demand. The proposed approach allows an estimation of economic value of water by obtaining economic derived water demands for each module individually. The value of water will depend on the final product and on the water production function in each crop [48]. According to Young [49], PMP is an appropriate method to obtain water demand functions in the agricultural sector.

PMP used for water allocation and pricing policies assessment has been applied in different countries. Howitt et al. [50] applied a calibrated model based on PMP, the statewide agricultural production model, to show how a flexible water market can reduce the revenue losses from drought. The results showed a reduction in the revenue losses from drought up to $30 \%$ in the irrigated agriculture of California. In Ecuador, Franco-Crespo and Sumpsi Viñas [51] assessed the economic impacts of a pricing policy, as well as a water delivery scheme. Cortignani and Severini [52] included in their model deficit irrigation techniques that were not observed in the base period, in order to conclude whether the farmers would adopt these technologies in face of increases in water costs, reductions in water availability, and changes in products prices. Watto and Mugera [53] employed a PMP model in a province of Pakistan, to estimate the derived demand of groundwater for irrigation; they also concluded that a pricing policy could promote an efficient use of water among farmers. Finally, Gallego-Ayala, Gomez-Limon, and Arriaza [54], used a PMP model with multiple criteria economic sustainability, social sustainability, and environmental sustainability, which enable to them compare different pricing instruments.

PMP has also been used to evaluate economic and spatial impacts of scarcity and to assess policies relating irrigation agriculture in México and in other countries [55-58]. Likewise, new methodologies and variations that use PMP have been developed $[59,60]$ to improve some shortcomings of the methodology, such as maximum entropy [61].

\subsection{Positive Mathematical Programming}

The original positive mathematical programming methodology consists of three stages following Howitt [62]. In the first stage, a linear production programming model is solved maximizing net benefits. In this model, a calibration constraint is added to the set of general resource constraints, which restricts activities at the production levels observed in the base year. In the second stage, the shadow prices obtained from the calibration constraint are used to a quadratic cost function parameterization. Finally, in the third stage, a non-linear constrained profit maximization program is solved. The objective function is defined by the non-linear calibrated cost function and a production function, subject to resource availability restrictions.

PMP assumes that farmers in a given region make optimal decisions when facing environmental, economic, technological, and commercial conditions, which would be difficult to consider as constraints in a mathematical programming model, since one would have to include constraints that cannot be justified by microeconomics theory [46]. The PMP approach follows the principles of production economics constrained optimization in which marginal costs equal marginal revenue, under land or water constrained conditions. But in addition, PMP assumes that the observed input use in production 
is optimal, and the method self-calibrates to these baseline conditions. That avoids overspecialization often found in pure linear programming. Consequently, when formulating the model through PMP, the model is calibrated without needing to consider this problem.

\subsubsection{Step I: Linear Calibration Program}

The first step to develop the PMP model is the linear production programming model, to which calibration constraints are added. This is expressed as:

$$
\operatorname{Max} \mathrm{Z}=\sum_{g} \sum_{i}\left(p_{i} y_{g i}-c_{g i}\right) x_{g i}
$$

subject to:

$$
\begin{gathered}
\sum_{i} a_{g i j} x_{g i j} \leq b_{g j} \forall g, j \\
x_{g i} \leq \bar{x}_{g i}+\varepsilon \\
x_{g i} \geq 0 \forall i
\end{gathered}
$$

where the sum of the net benefit of the modules $(Z)$ is maximized in the objective function (Equation (1)), which is equal to the price of crop $i\left(p_{i}\right)$ multiplied by the yield per hectare of crop $i$ in module $g\left(y_{g i}\right)$, minus the cost of cultivating one hectare of crop $i$ in module $g\left(c_{g i}\right)$ multiplied by decision variable $x_{g i}$, which is the optimal number of hectares planted with crop $i$ in module g. The resource constraints (Equation (2)) are given by the sum of technical coefficients $a_{g i j}$, representing production input $j$ used in a hectare planted with crop $i$, in the module $g$, multiplied by the decision variable, limited to the amount of resources. The limited resources are land and water, represented by parameter $b_{g j}$. A calibration constraint (Equation (3)) is added, which limits the decision variable $x_{g i}$ to the value observed in the base year $\bar{x}_{g i}$, to which a decoupling factor $\varepsilon$ is added to ensure that the level of activity could be equal to that observed, $\varepsilon=0.001$ was used. Finally, there are the non-negativity conditions, which restrict the presence of $x_{g i}$ in the solution to zero or positive values (Equation (4)).

\subsubsection{Step II: Estimating Quadratic Cost Function}

Total cost function is given by:

$$
\begin{gathered}
\mathrm{TC}_{g i}\left(x_{\text {gi,land }}\right)=\alpha_{g i} x_{\text {gi,land }}+\frac{1}{2} \gamma_{g i} x_{\text {gi,land }}^{2} \\
\alpha_{g i}=c_{g i}-\mu_{g i} \\
\gamma_{g i}=\frac{2 \mu_{g i}}{\bar{x}_{g i}} .
\end{gathered}
$$

The total cost function (TC) is computed for every crop in each module (Equation (5)) and is calibrated exactly to the observed values of production and use of inputs, by using the shadow price vector $\mu_{g i}$ of the calibration constraint (Equation (3)). This vector is included in the parameter associated with intercept $\alpha_{g i}$, as well as in slope $\gamma_{g_{i}}$ of the total cost function.

\subsubsection{Step III: Calibrated Non-Linear Optimization Program}

In this stage, the sum of total net benefit is maximized with a non-linear objective function, subject to the availability of the resources of each module. The objective function is:

$$
\operatorname{Max} \mathrm{Z}=\sum_{g} \sum_{i}\left(p_{i} y_{g i}\right) x n l_{\text {gi,land }}-\sum_{g} \sum_{i}\left(\alpha_{g i}+\frac{1}{2} \gamma_{g i} x n l_{\text {gi,land }}\right) x n l_{\text {gi,land }}
$$


subject to:

$$
\begin{array}{ll}
\sum_{i} a_{\text {gi,land }} x n l_{\text {gi,land }} \leq b_{\text {g,land }} & \forall g \text {, land, } \\
\sum_{i} a_{\text {gi,water }} x n l_{\text {gi,land }} \leq \delta \cdot b_{\text {g,water }} & \forall g \text {, water, } \\
x n l_{\text {gi,land }} \geq 0 & \forall \text { i, land. }
\end{array}
$$

In this model, the objective function is maximized (Equation (8)), which is the sum of the total net benefits of all modules in the irrigation district, the decision variable being the hectares sown with each crop in each module $x n l_{\text {gi,land }}$, to which the quadratic cost function calibrated by PMP (Equation (5)) is integrated. There is also the per-module land availability constraint (Equation (9)), which is the same as the restriction used in the linear model. The per-module water constraint (Equation (10)) is used to create drought scenarios, where $b_{g, \text { water }}$ is the annual water available for each module, and the $\delta$ coefficient of water availability, which can have values of $0<\delta<1$. Equation (11) represents the non-negativity conditions.

Some assumptions are made with this model. First, water is available but limited for each module in an agricultural year and it is not interchangeable among them. Secondly, annual available water is interchangeable among crops within a module and is assigned according to crop seasonality, and users of each module make decisions maximizing the module's net income.

\subsubsection{Using a Calibrated Non-linear Optimization Program of a Water Market}

Once the model was calibrated as established in the first and second steps, a second calibrated model was formulated that allows the export and import of water among irrigation modules, to evaluate the possibility of creating a water market in the irrigation district as a policy that compensates for the economic impacts of a possible drought and allows efficient use within the district. This model allows for the identification of which modules would become water exporters, and which would become importers. The model also makes it possible for us to evaluate economically optimal crop shifting patterns, with and without water markets, under the different water availability scenarios.

$$
\operatorname{Max} Z=\sum_{g} \sum_{i}\left(p_{i} y_{g i}\right) x m_{g i \text { land }}-\sum_{g} \sum_{i}\left(\alpha_{g i}+\frac{1}{2} \gamma_{g i} x m_{g i, l a n d}\right) x m_{g i, l a n d}
$$

Subject to:

$$
\begin{aligned}
& \sum_{i} a_{\text {gi,land }} x m_{g i \text {,land }} \leq b_{g, \text { land }} \forall g_{\text {, land }} \quad \forall \text { g,land } \\
& \sum_{i} a_{g i, \text { water }} x m_{g i, l a n d} \leq\left(\delta \cdot b_{g, \text { water }}\right)+I W_{g, \text { water }}-E W_{g, \text { water }} \quad \forall g \text {, water } \\
& \sum_{g} I W_{g, \text { water }}=\sum_{g} E W_{g, \text { water }} \quad \forall g, \text { water } \\
& E W_{g, \text { water }} \leq b_{g, \text { water }} \cdot \delta \cdot \operatorname{expcap} \quad \forall g \text {, water } \\
& I W_{g, \text { water }}, E W_{g, \text { water }}, x m_{\text {gi,land }} \geq 0
\end{aligned}
$$

The decision variables are $x m_{g i}, l a n d$, which is the number of hectares planted with crop $i$ within each module $g$, the imported water per module $I W_{g, \text { water }}$, and exported water per module $E W_{g, \text { water }}$. The constraint of water available by module is its availability, plus the amount imported, minus the amount exported (Equation (14)). Total water that is imported by the modules must be the same as they export to uphold mass balance (Equation (15)). Each module has an export water restriction, which is $50 \%$ (expcap $=0.50)$ of the available water in both shortage scenarios (Equation (16)). The decision 
variables must comply with the non-negativity condition (Equation (17)). For this model, in addition to the assumptions mentioned in step three, it is assumed that the necessary infrastructure for the water market and sufficient storage capacity exist.

The mathematical programming model conformed by Equations (1)-(17) was formulated and solved using GAMS (general algebraic modeling system) software [63].

\subsection{Dataset}

The model requires various datasets describing hectares planted, estimated water use, production costs, and agricultural commodity prices. All datasets correspond to each crop and irrigation module. Most of this information was provided by the Irrigation District 011 head office and the Irrigation District 011 Limited Liability Association [64-67].

\subsubsection{Crop Mix Selection}

Analyzing data from 2008 to 2017 on the crop pattern chosen for each module, it can be seen that there are no differences in the representativeness of the crops selected; thus, the crop pattern chosen for each module is representative of the conditions and constraints faced by each one. The last available crop pattern was used as the baseline, which corresponds to the 2016-2017 agricultural year.

The most representative crops in ID011 were barley, wheat, maize, sorghum, and alfalfa, which, in the base year, accounted for $92 \%$ of the total area sown and used $90 \%$ of total irrigation water in the district. Each module has different representative crops; the crops that represented more than $1 \%$ of the area sown, within each module in the base year, were selected. These include asparagus, broccoli, strawberry, lettuce, and beans. The excluded crops do not represent a significant portion of the planted area or water use in the base year. These crops include coriander, zucchini, peanut, chili, garbanzo, and garlic.

In all modules, the selected crop pattern (Table 1) represents at least $97 \%$ of the area sown and at least $84 \%$ of water used. The sum of all the selected crop pattern represents $97.3 \%$ of the 158,663 hectares (ha) planted and $95.6 \%$ of the 1.100 million cubic decameters used in the Irrigation District 011 in the 2016-2017 base year.

Table 1. Base crop mix for Irrigation District 011 in the 2016-2017 base year.

\begin{tabular}{ccc}
\hline Crop & Land Use (ha) & Water Use (dam ${ }^{\mathbf{3}}$ ) \\
\hline Alfalfa (Medicago sativa) & 4312 & 42,801 \\
Oat (Avena sativa) fodder & 269 & 2150 \\
Broccoli (Brassica oleracea botrytis) & 2449 & 23,101 \\
Barley (Hordeum vulgare) & 35,559 & 301,061 \\
Onion (Allium cepa) & 531 & 3828 \\
Asparagus (Asparagus officinalis) & 4652 & 29,164 \\
Strawberry (Fragaria mexicana) & 576 & 18,214 \\
Common bean (Phaseolus vulgaris) & 684 & 10,432 \\
Lettuce (Latuca sativa) & 1162 & 8329 \\
Corn (Zea mays) grain & 59,593 & 287,191 \\
Sorghum (Sorghum bicolor) grain & 20,965 & 79,305 \\
Tomatillo (Physalis philadelphica) & 633 & 8665 \\
Wheat (Triticum sp.) grain & 22,357 & 235,169 \\
Carrot (Daucus carota) & 641 & 2399 \\
Total & 154,383 & $1,051,809$ \\
$\%$ Represented in the Irrigation District 011 & $97.3 \%$ & $95.6 \%$ \\
\hline Source: CONAGUA [65,66]. \\
\hline
\end{tabular}




\subsubsection{Prices, Costs, and Yields}

For these datasets, average values per module and crop of the last three agricultural years (2014-2015 to 2016-2017) were used. Rural price does not vary significantly among modules; however, prices reported by each module to the Irrigation District 011 head office were used. These prices are consistent with data available from the Secretariat of Agriculture and Rural Development (SAGARPA) and the Secretariat of Economy [68,69]. Average production costs per crop used and module are reported every agricultural year to the Irrigation District 011 head office. Differences were detected in production costs, particularly in vegetable crops. For example, production costs of asparagus in the Module Abasolo module is US $\$ 2550$ higher than Module Irapuato. Within grain production, the difference among production costs is not as big as vegetable crops; the highest cost in Maize was US $\$ 1300$ per hectare, while the lowest cost was US\$957. The same applies to yields, both in vegetable and perennial crops.

Table 2 summarizes average values of Irrigation District 011 for the 2014-2015 to 2016-2017 agricultural years of commodity (rural) prices, costs, and yields of the crop pattern selected in the model. Disaggregated data per module in the model were used.

Table 2. Average rural prices, costs, and yields of the 2014-2015 to 2016-2017 agricultural years in Irrigation District 011.

\begin{tabular}{cccc}
\hline Crop & Avg. Rural Price (US\$/t) & Avg. Cost (US\$/ha) & Yield (t/ha) \\
\hline Alfalfa (Medicago sativa) & 110.53 & 1226.46 & 25.92 \\
Oat (Avena sativa) fodder & 87.85 & 732.63 & 11.75 \\
Broccoli (Brassica oleracea botrytis) & 217.86 & 2410.83 & 14.95 \\
Barley (Hordeum vulgare) & 226.45 & 936.60 & 6.21 \\
Onion (Allium cepa) & 172.32 & 1987.44 & 38.19 \\
Asparagus (Asparagus officinalis) & 1779.07 & 4860.83 & 4.74 \\
Strawberry (Fragaria mexicana) & 474.28 & 7568.29 & 31.96 \\
Common Bean (Phaseolus vulgaris) & 826.93 & 1030.26 & 2.51 \\
Lettuce (Latuca sativa) & 159.71 & 1696.62 & 24.96 \\
Corn (Zea mays) grain & 182.50 & 1106.90 & 11.31 \\
Sorghum (Sorghum bicolor) grain & 178.53 & 965.15 & 7.86 \\
Tomatillo (Physalis philadelphica) & 219.32 & 1449.47 & 24.30 \\
Wheat (Triticum sp.) grain & 194.63 & 962.87 & 6.59 \\
Carrot (Daucus carota) & 80.07 & 1255.39 & 41.25 \\
\hline
\end{tabular}

\subsubsection{Water Use}

Water use estimates were obtained through monthly water use reports from Irrigation District 011 [66]. Reports include a breakdown of water use by crop and module, and also by source including dams, private wells, and government wells, from where information on water sent to each crop can be obtained. Likewise, annual water delivery reports from the Irrigation District 011 head office [66] were used. These reports include the total water sent to each crop and module in an agricultural year, for the dataset used. Water deliveries for the 2016-2017 base year were used as a baseline.

There is a wide range of water use estimates between modules within the irrigation district. Water use varies depending on the size of the module, the water source (dams or wells), and the crops grown. There are modules that use a large amount of groundwater, which is expected to have a higher shadow price because it is largely assigned to higher-value crops such as asparagus, strawberry, and broccoli. On the other hand, there are modules that mainly use surface water, which is generally cheaper and allocated for grain and other field crops production.

In the model, each module faces constraints on resource availability. Total volume of water used in the 2016-2017 base year was considered as the constraint on available water for each module. 
The water use coefficient for each crop corresponds to the average volume applied to each crop in each module. Water volume was expressed in cubic decameters $\left(\mathrm{dam}^{3}\right)$.

Different drought scenarios were considered, by the reduction of water availability from $100 \%$ to $50 \%$ in $10 \%$ intervals, using the water availability parameter $(\delta)$ in the water availability constraint (Equation (10)). The model assumes that farmers make decisions to maximize the net benefit of their production in an agricultural year. The non-linear production model chooses the optimal crop pattern, to the point where the marginal product of the selected crops is equal to the marginal cost. For the model of water market, the same water availability parameter $(\delta)$ was used in the water availability constraint with market possibility (Equation (14)); this parameter had values of 0.75 for the $25 \%$ shortage and 0.50 for the $50 \%$ shortage.

\section{Results}

The calibrated linear programming model (Equations (1) to (4)), the parameterization of the quadratic cost function (Equations (5) to (7)), the non-linear production model (Equations (8) to (11)), and the model to evaluate the feasibility of creating a water market within the district (Equations (12) to (17)) were formulated and solved using GAMS software following McCarl's user guide [70]. The model was calibrated to the observed values of the 2016-2017 base year in steps one and three.

\subsection{Shadow Prices of Water in the Irrigation Modules}

Due to the heterogeneity of the modules in those inputs herein included, the shadow prices summarized in Table 3 have differences among the modules. The Corralejo (10) module maintains the lowest shadow price in the district even with an extreme $50 \%$ shortage; this is because it has a greater use of surface water and wheat is well represented within the module. It is necessary to consider that wheat and oat crops have the lowest net income in ID011. Moreover, since wheat is a crop with high water consumption, it needs to be recognized that the marginal product value of water used in its cultivation is low.

On the other hand, it can be seen that modules that have a low representation of wheat, oats, and barley, and a high percentage in area sown with maize, sorghum, and vegetables, maintain a high shadow price in each availability level as in the case of the modules: Acámbaro (M01), Salvatierra (M02), Valle (M04), Cortázar (M05), and Irapuato (M07). When water becomes scarcer in these modules, the shadow price increases in a greater proportion than elsewhere in the district. Vegetable crops have the highest net income and are mainly irrigated with water from wells, which is why modules with higher groundwater use have a higher shadow price. That is the case of the modules: Salvatierra (M02) with 26\% groundwater of its total water delivery in the base year, Cortazar (M05) with 32\%, Valle (M04) with 37\%, and Irapuato (M07) with 54\%. Although within the Jaral (M03) module the use of groundwater is almost $60 \%$ of the total use of water, it is used for low net price crops particularly barley, for this reason the shadow prices is low compared to other modules, which use groundwater for vegetable crops.

Table 3. Shadow prices of water in the irrigation modules of the Irrigation District 011 (US\$/dam ${ }^{3}$ ).

\begin{tabular}{cccccccccccc}
\hline Water (\%) & M01 & M02 & M03 & M04 & M05 & M06 & M07 & M08 & M09 & M10 & M11 \\
\hline 100 & 14 & 37 & 17 & 24 & 35 & 18 & 16 & 23 & 17 & 7 & 16 \\
90 & 25 & 37 & 24 & 30 & 35 & 24 & 16 & 23 & 17 & 7 & 16 \\
80 & 46 & 41 & 31 & 42 & 35 & 30 & 16 & 23 & 17 & 11 & 16 \\
70 & 70 & 52 & 39 & 54 & 38 & 37 & 30 & 23 & 17 & 17 & 16 \\
60 & 94 & 64 & 47 & 66 & 62 & 43 & 47 & 36 & 24 & 23 & 18 \\
50 & 118 & 86 & 65 & 78 & 85 & 51 & 65 & 62 & 43 & 28 & 32 \\
\hline
\end{tabular}

Nomenclature: M01: Acámbaro, M02: Salvatierra, M03: Jaral, M04: Valle, M05: Cortazar, M06: Salamanca, M07: Irapuato, M08: Abasolo, M09: Huanímaro, M10: Corralejo, M11: La Purísima. 
The water rate paid by farmers in the 2016-2017 agricultural year was $\$ 26.31$ per irrigated hectare, which is the price charged by the National Water Commission (CONAGUA) through the Irrigation District 011 head office. Taking into account that one irrigated hectare has an average volumetric distribution of $3.4 \mathrm{dam}^{3}$, the rate is $\$ 7.73$ per dam ${ }^{3}$. Therefore, with the exception of the Corralejo (M10) module, the price is consistently 1.8 to 4.7 times higher than the rate paid by users, based on the water availability observed in the 2016-2017 agricultural year. Considering a $25 \%$ shortage, this proportion increases from 1.8 to 5.8 times the rate paid, and with an extreme $50 \%$ shortage, it would increase from 3.6 to 14.8 times.

Figure 2 shows the different marginal values of the water obtained, given the different availability scenarios. These values represent estimated water shadow price for every additional cubic decameter of water in an agricultural year.

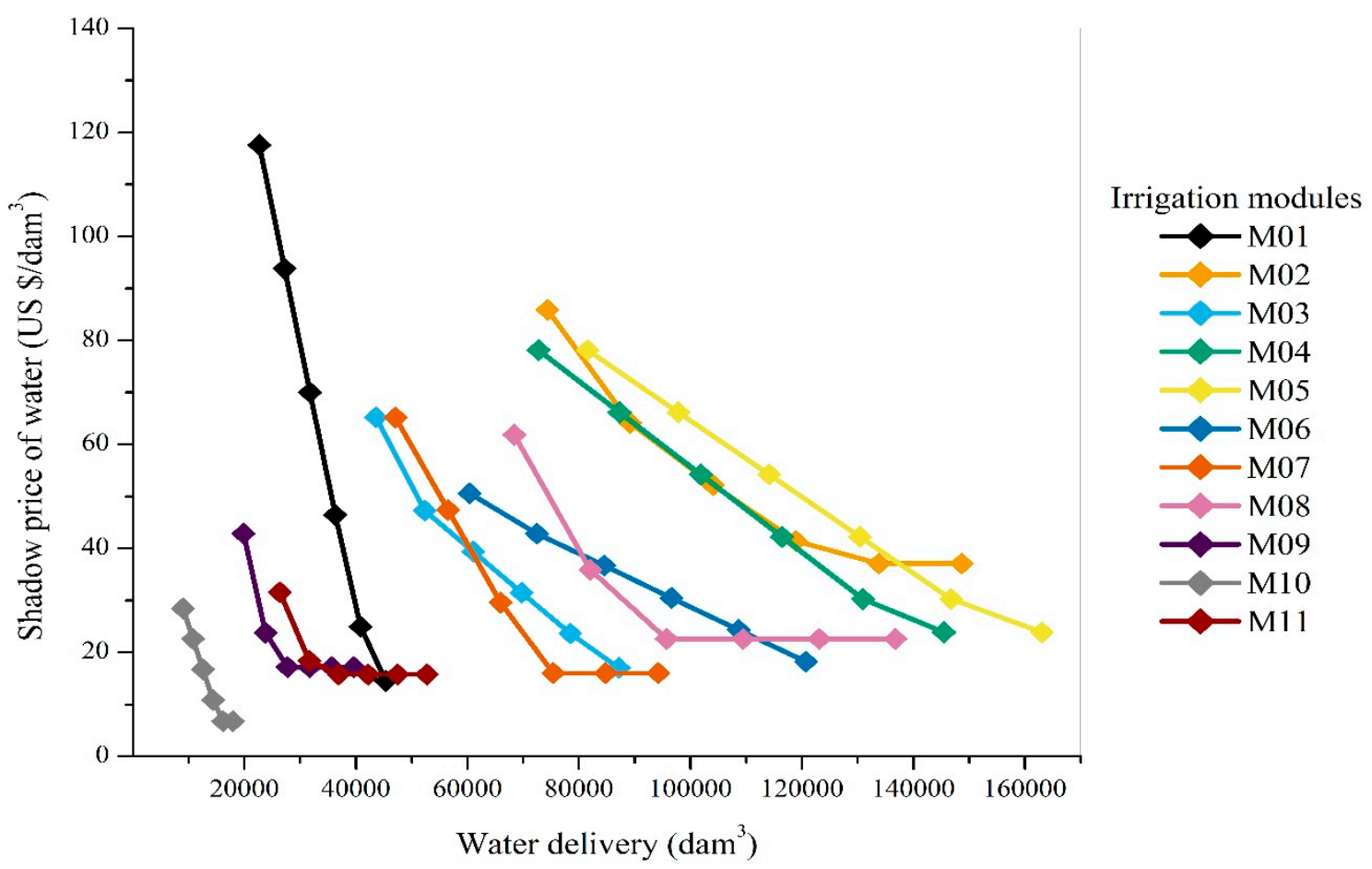

Figure 2. Shadow prices of water in the irrigation modules of the Irrigation District 011. Nomenclature: M01: Acámbaro, M02: Salvatierra, M03: Jaral, M04: Valle, M05: Cortazar, M06: Salamanca, M07: Irapuato, M08: Abasolo, M09: Huanímaro, M10: Corralejo, M11: La Purísima.

As noticed, the Acámbaro (M01), Salvatierra (M02) and Cortázar (M05) modules present the highest shadow price. Under extreme drought conditions, shadow price increases to $\$ 118, \$ 86$, and $\$ 85$ dollars per cubic decameter, respectively. This is because crops with high net income are well represented, in Salvatierra (M02) with carrots and tomatillos, and in Cortázar (M05) with broccoli, lettuce, and asparagus. The Acámbaro (M01) module is particularly striking; crops with a high net price are not sown in this module, with maize cultivation accounting for $80 \%$ of the module area. As one could expect, its shadow price is low at $100 \%$ and $90 \%$ availability. However, reducing available water below $70 \%$ increases its marginal value more than in the other modules. This can be explained by the technical coefficient of water in alfalfa and maize crops, since in this module, these coefficients are low compared to the district average; hence, water is very productive in these crops. In addition to the water being scarcer, the model first chooses the crops with the highest net price, but also those that use the least water. The Valle module behaves similarly to this group of modules; although high-value crops are not sown in this module, its yields are above the mean.

The average price elasticities obtained for the district, summarized in Table 4 , are in the -0.33 to -0.65 inelasticity range; these values are within the range of previous estimates found in the 
meta-analysis made by Scheierling et al. [71] and in results obtained for other regions in Mexico [47,72]. In general, the elasticities of the district behave in a similar way. However, the elasticity of the Cortázar (M05) module has a high value when availability decreases to $70 \%$. An explanation for this result is the predominance of asparagus and lettuce in the module; both high-value crops provide a higher level of profit per unit of applied water.

Table 4. Water price-elasticity demand in the irrigation modules of the Irrigation District 011.

\begin{tabular}{ccccccccccccc}
\hline $\begin{array}{c}\text { Water } \\
(\%)\end{array}$ & M01 & M02 & M03 & M04 & M05 & M06 & M07 & M08 & M09 & M10 & M11 & Mean \\
\hline 100 & - & - & - & - & - & - & - & - & - & - & - & - \\
90 & -0.20 & - & -0.32 & -0.44 & - & -0.37 & - & - & - & - & - & -0.33 \\
80 & -0.20 & -1.05 & -0.41 & -0.36 & - & -0.52 & - & - & - & -0.25 & - & -0.46 \\
70 & -0.33 & -0.58 & -0.60 & -0.54 & -1.74 & -0.72 & -0.22 & - & - & -0.31 & - & -0.63 \\
60 & -0.53 & -0.75 & -0.85 & -0.77 & -0.33 & -0.99 & -0.33 & -0.34 & -0.48 & -0.52 & -0.99 & -0.62 \\
50 & -0.81 & -0.63 & -0.57 & -1.10 & -0.57 & -1.10 & -0.57 & -0.34 & -0.32 & -0.79 & -0.34 & -0.65 \\
\hline \multicolumn{10}{c}{ Source: Results of this research. } \\
\hline
\end{tabular}

\subsection{Efficient Water Market in the ID011}

The objective of the second component of this research was to evaluate the creation of a water market within the irrigation district, which allows water transfer among modules, from both sources surface water and groundwater, as an economically efficient mechanism to address drought effects. This mechanism was evaluated using the PMP calibrated model, formed by the same three-stage process as previously described. The final water market model is formed by the objective function of the non-linear production model (Equation (12)) and resource constraints (Equations (13) to (17)). Two scenarios were considered: The first with a $25 \%$ reduction in total water availability in the district, and the second with a $50 \%$ total reduction. The objective of this market was to examine gains from a more economically efficient allocation of water.

This is achieved by maximizing overall net returns at the district level, which often results in supplying water first to higher value crops. The model also allows us to analyze the behavior of this market under drought scenarios, as well as changes in irrigated land and optimal crop pattern. The results, obtained through the calibrated model (Equations (8) to (11)) with 25\% and 50\% water shortages, were compared to a scenario in which there is a drought, but not a water market.

Water markets allow transferring water among users including those from low-value crops to higher value crops, as well as from crops with higher water use to those with lower use. This allows readjustment and adaptation in the total irrigated area of the district as well as in the optimal crop pattern.

Considering the shadow prices obtained, those modules with a low shadow price tend to export water to modules with a higher shadow price. As shown in Figure 3, the Acámbaro (M01), Salvatierra (M02), and Valle (M04) modules would become water importers, which is consistent with the results of water shadow prices. The largest importer of water would be the Salvatierra (M02) module, with 37,657.5 dam $^{3}$. The Abasolo (M08), Huanímaro (M09), Corralejo (M10), and La Purísima (M11) modules would be the largest water exporters. In particular, the Corralejo (M10) module would export 6649.4 $\mathrm{dam}^{3}$ of its available water under this drought scenario, for two main reasons: Firstly, low-value crops are cultivated (sorghum and wheat) in it, and secondly, it has limited access to groundwater. On the other hand, the modules Jaral (M03) and Cortazar (M05) would participate in the water market exporting a low rate of their available water, due to their high-water consumption from wells which is greater than their use of surface water, and to the cultivation of vegetable crops, particularly broccoli, asparagus, and lettuce. 


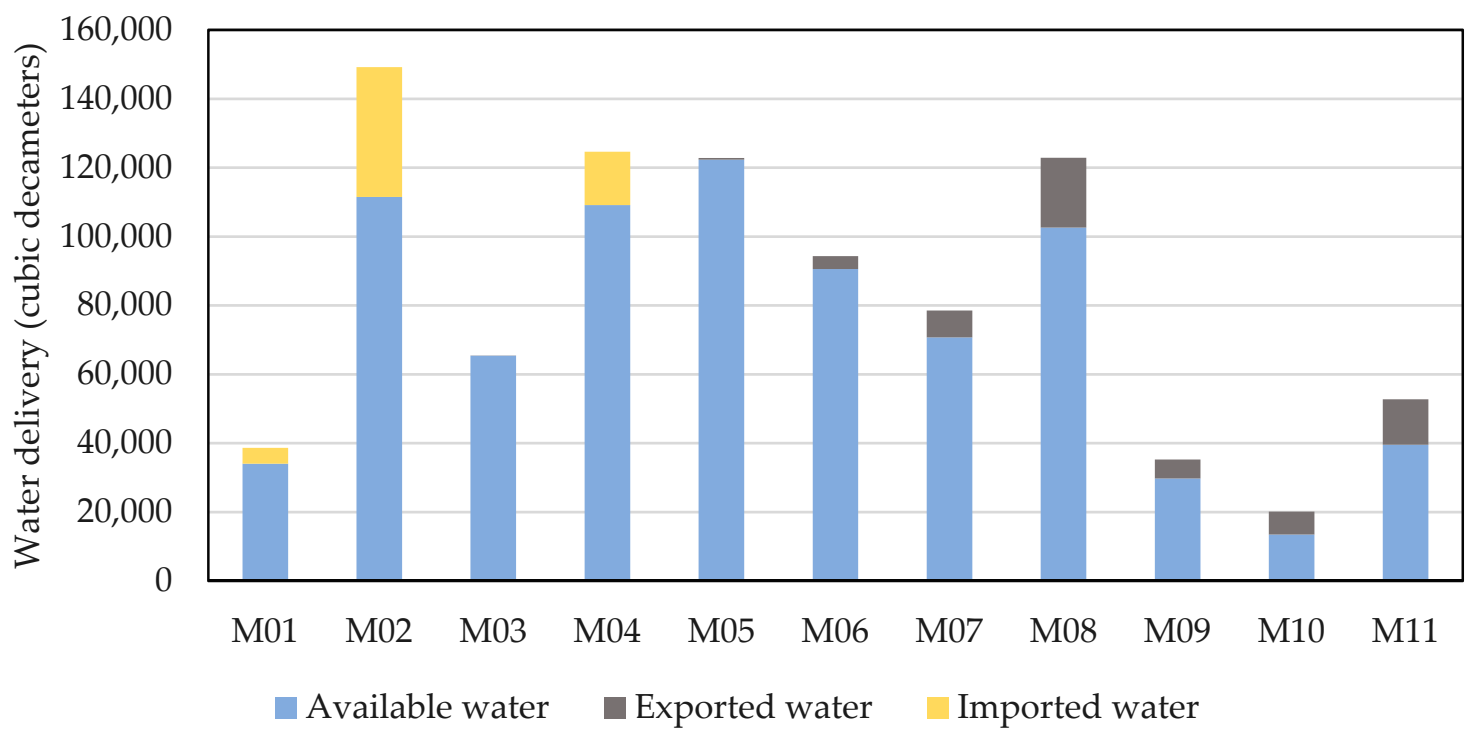

Figure 3. Breakdown of water use under $25 \%$ shortage scenario with water market.

In the case of a $50 \%$ shortage (Figure 4), the behavior of the modules will change with respect to the previous scenario. Under this scenario, the Salvatierra (M02) and Cortázar (M05) modules would be the largest importers with $9369.8 \mathrm{dam}^{3}$ and $8807.5 \mathrm{dam}^{3}$, respectively. The participation of Cortázar Module would change in this scenario, whereas in 25 shortage scenario, participates exporting water in the $50 \%$ scenario would import water. The Salamanca (M06) module would be the largest exporter with $17,844.6 \mathrm{dam}^{3}$, followed by the Abasolo (M08) module which would export $5477.4 \mathrm{dam}^{3}$. As in the previous scenario, the Jaral (M03) participate in the water market with a 50\% shortage, but in a smaller quantity, exporting $1881.4 \mathrm{dam}^{3}$. The La Purísima (M11) module would not export as much water as in the $25 \%$ scenario, even though its resource depends almost entirely on surface water; the condition of this module that enables it to overcome a drought of such magnitude is its grain crop yields, which are above average. The differences among modules, such as soil characteristics and the use of technology have an impact on the yields of the modules.

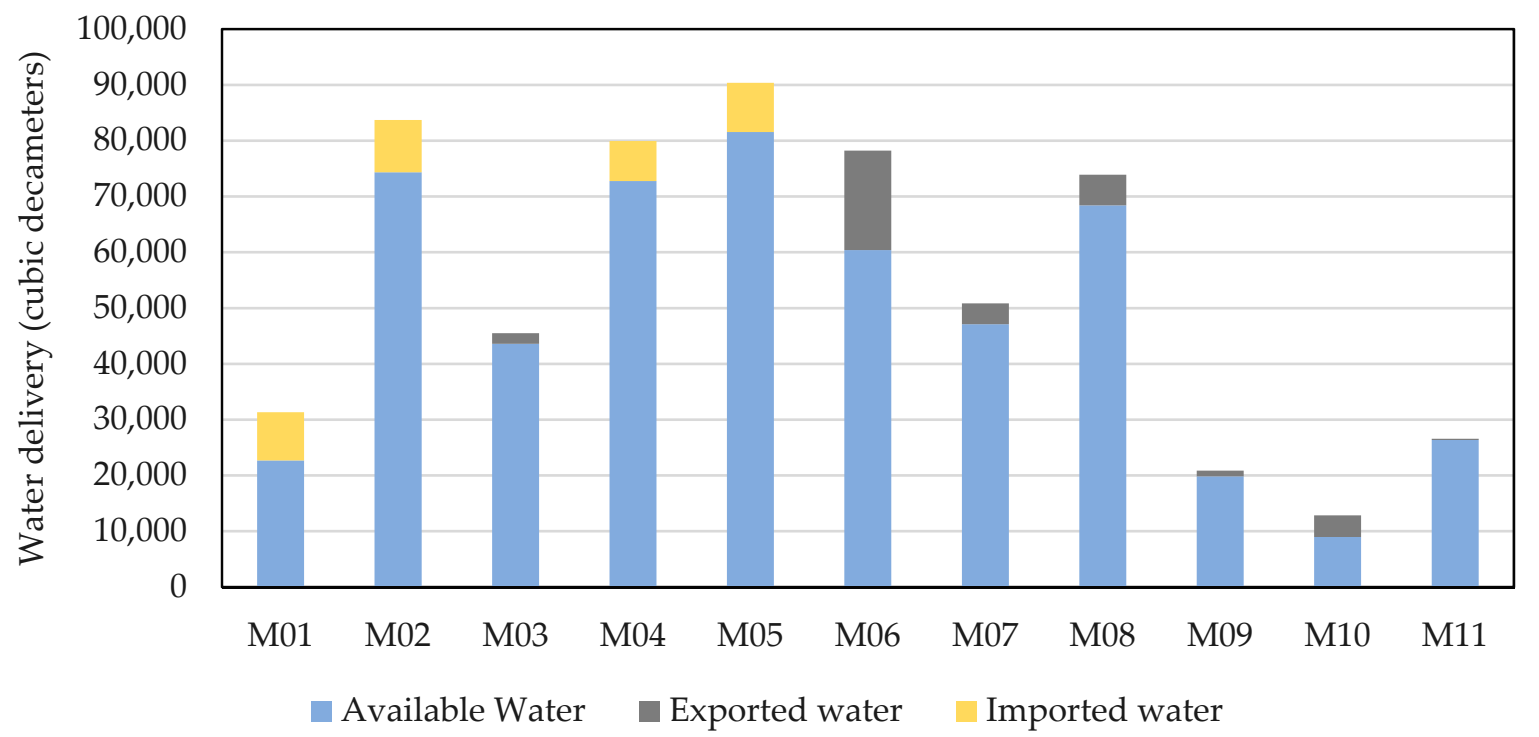

Figure 4. Breakdown of water use under $50 \%$ shortage scenario with water market.

The differences among the use of irrigation technologies can be seen in the technical coefficient of water. Modules as Acámbaro (M01), Cortázar (M05), and Salamanca (M06), have lower water 
technical coefficient in grain crops. For instance, the water technological coefficient in Cortázar (M05) module is 5.42 cubic decameters per hectare, while in Irapuato (M07) module is 11.16. In maize, the irrigation technology used is more homogeneous. In wheat for instance, Acambaro (M01) water technology coefficient is 8.051 cubic decameters per hectare, while in La Pruisima (M11) module is 13 cubic decameters per hectare. In vegetable crops, these differences also exist but are less significant than in grain crops.

In response to drought, producers would be expected to change their crop patterns. Our modeling approach provides an estimate of these shifting cropping patterns as agricultural areas adapt to drought with and without water markets (Table 5). When water use is optimized, the cropping pattern in case of drought reassigns water to crops with a higher net price and/or to crops with low water use. In all cases, the autumn-winter crops, namely oats and wheat, are those that have the greatest losses in planted area. These two crops generate a lower net income and have high water use rates compared to other crops such as maize and sorghum. Water markets allow irrigated land to be used for these crops and others with a greater net price or less water use.

In the first scenario, with a $25 \%$ shortage, it is noticed that water markets favor vegetable crops, particularly common bean, tomatillo, and carrot crops. Excluding alfalfa, perennial crops have greater losses with a water market because of asparagus and strawberry, which are water intensive. According to Reference [73], as water becomes scarcer, the likelihood of farmers choosing perennial crops decreases. Spring-summer crops (maize and sorghum) benefit from the water market; even sorghum would have a larger planted area, $7.3 \%$ more, compared to the non-market model.

In the second scenario, with a 50\% shortage, the results show a similar behavior when the optimal crop pattern is selected by the model. In general, autumn-winter vegetable crops benefit from the market as in the previous case, particularly common bean with $62.95 \%$ increase followed by carrot, lettuce, and tomatillo. Wheat would have the greatest decrease in planted area, with wheat being the most affected by the market in terms of area, with a $90.64 \%$ reduction. The perennial alfalfa and spring-summer maize crops would also increase in area with the market. In both scenarios, a water market in the irrigation district allows farmers to plant a larger area, with a $0.22 \%$ and $0.40 \%$ total gain for the $25 \%$ and $50 \%$ shortage scenarios, respectively.

Table 5. Irrigated crop area (in hectares) with and without drought and water market.

\begin{tabular}{|c|c|c|c|c|c|c|c|}
\hline \multirow[b]{2}{*}{ Crop } & \multirow[b]{2}{*}{$\begin{array}{l}\text { Base } \\
\text { Land } \\
\text { Use }\end{array}$} & \multicolumn{3}{|c|}{$25 \%$ Shortage } & \multicolumn{3}{|c|}{$50 \%$ Shortage } \\
\hline & & $\begin{array}{c}\text { Land Use } \\
\text { without } \\
\text { Market }\end{array}$ & $\begin{array}{c}\text { Land Use } \\
\text { with } \\
\text { Market }\end{array}$ & $\begin{array}{c}\text { Percent } \\
\text { Change } \\
(\%)\end{array}$ & $\begin{array}{c}\text { Land Use } \\
\text { without } \\
\text { Market }\end{array}$ & $\begin{array}{c}\text { Land Use } \\
\text { with } \\
\text { Market }\end{array}$ & $\begin{array}{c}\text { Percent } \\
\text { Change } \\
(\%)\end{array}$ \\
\hline Alfalfa & 4311 & 4049 & 4180 & 3.24 & 3360 & 3567 & 6.15 \\
\hline Asparagus & 4652 & 4624 & 4588 & -0.78 & 4459 & 4412 & -1.06 \\
\hline Barley & 35,559 & 28,239 & 26,942 & -4.59 & 11,378 & 12,021 & 5.65 \\
\hline Broccoli & 2449 & 2222 & 2211 & -0.49 & 1456 & 1444 & -0.83 \\
\hline Carrot & 641 & 630 & 637 & 1.08 & 584 & 600 & 2.72 \\
\hline $\begin{array}{c}\text { Common } \\
\text { bean }\end{array}$ & 684 & 590 & 687 & 16.40 & 211 & 344 & 62.95 \\
\hline Corn & 59,593 & 57,705 & 58,304 & 1.04 & 49,721 & 51,050 & 2.67 \\
\hline Lettuce & 1162 & 1157 & 1151 & -0.52 & 1037 & 1055 & 1.73 \\
\hline Oats & 267 & 131 & 91 & -30.51 & 56 & 60 & 6.51 \\
\hline Onion & 531 & 529 & 524 & -0.87 & 504 & 503 & -0.21 \\
\hline Sorghum & 20,965 & 21,993 & 23,596 & 7.29 & 20,527 & 20,264 & -1.28 \\
\hline Strawberry & 576 & 568 & 540 & -4.88 & 485 & 471 & -2.88 \\
\hline Tomatillo & 632 & 623 & 629 & 0.94 & 581 & 587 & 1.04 \\
\hline Wheat & 22,338 & 5881 & 5146 & -12.49 & 1798 & 168 & -90.64 \\
\hline Total & 154,360 & 128,939 & 129,224 & 0.22 & 96,157 & 96,545 & 0.40 \\
\hline
\end{tabular}


When farmers in the irrigation district face a severe drought, they are more likely to choose planting a single cycle, either autumn-winter (barley and wheat) or spring-summer (maize and sorghum). With the optimal model under drought scenarios, the wheat crop planted area should be decreased for the reasons mentioned above. However, in reality this does not happen. Instead, farmers decide to plant this crop for the commercialization benefits they receive for this and other grains from the Bureau of Market Services and Agricultural Market Development (ASERCA), which, through incentives, ensures its commercialization and the payment of a base price to farmers. Considering the problem of wheat, attempts have been made in recent years to develop and encourage the use of an improved wheat which needs less irrigation than the type traditionally grown.

The income results show the per-module and aggregated economic effects of a drought under both cases: With the water market mechanism and without it. Table 6 summarizes the results of a $25 \%$ shortage scenario. Without a water market, there would be a total loss of US\$11,121,417 in the district, whereas if a water market were created, this loss would be offset by $0.87 \%$, equivalent to a net added benefit of US $\$ 1,068,819$. The water market softens the impact of a drought for the irrigation modules and the irrigation district. In this case, with a water market, the Acámbaro (M01), Salvatierra (M02), and Valle (M04) modules have the greatest benefit in their net income when a water market is feasible; the first two benefit from the import of water. On the other hand, the export modules have losses in their net revenue with a water market in the $25 \%$ shortage scenario. Corralejo (M10) module has the greatest net revenue loss of 13.63\%, followed by Huanimaro (M09) and Abasolo (M08) modules.

Table 6. Module net revenues with and without $25 \%$ shortage and water market (in US\$1000).

\begin{tabular}{ccccc}
\hline Irrigation Modules & Base Revenue & $\begin{array}{c}\text { Drought without } \\
\text { Market }\end{array}$ & $\begin{array}{c}\text { Drought with } \\
\text { Market }\end{array}$ & $\begin{array}{c}\text { Percent Change } \\
\text { (\%) }\end{array}$ \\
\hline M01 & 5683.95 & 4579.35 & 5128.68 & 12.00 \\
M02 & $18,174.14$ & $16,187.05$ & $18,132.69$ & 12.02 \\
M03 & 8724.04 & 7562.27 & 7559.57 & -0.04 \\
M04 & $18,557.21$ & $15,997.98$ & $17,249.52$ & 7.82 \\
M05 & $20,719.60$ & $19,273.05$ & $19,256.25$ & -0.09 \\
M06 & $20,652.89$ & $19,177.45$ & $18,994.58$ & -0.95 \\
M07 & $13,854.32$ & $13,306.40$ & $12,639.99$ & -5.01 \\
M08 & $17,191.99$ & $16,420.36$ & $15,386.24$ & -6.30 \\
M09 & 3369.44 & 3594.55 & 3293.56 & -8.37 \\
M10 & 1654.88 & 1569.69 & 1355.80 & -13.63 \\
M11 & 4836.17 & 4629.05 & 4369.14 & -5.61 \\
Total & $133,418.62$ & $122,297.20$ & $123,366.02$ & 0.87 \\
\hline
\end{tabular}

Source: Results of this research.

Table 7 summarizes the results of the $50 \%$ shortage scenario. In this case, the Acámbaro (M01) module has the greatest income benefit, resulting from importing water and increasing the land sown with corn. The same happens in the Salvatierra (M02) and Valle (M04) modules, both gain net income from the land sown with common bean. The Cortázar (M05) module has a total net benefit with the water market for an increase in the land sown with broccoli, lettuce, asparagus, and corn, whereas the modules which export water have a total net loss, as the $25 \%$ shortage and water market scenario Corralejo (M10) has the greatest loss. Total district income would benefit by an additional US $\$ 990,212$ if a water market existed under this scenario. Therefore, creating a water market in a $50 \%$ shortage scenario would be economically feasible and would provide additional economic benefits for the irrigation district.

As can be seen in both scenarios, some modules obtain significant benefits from having access to a water market, particularly those that have competitive crops, with low costs, use of technology, and higher yields. Some modules would receive a lower net income compared to the drought and non-market scenario; the loss would be greater for those modules that export water and have low net price crops, as is the case of Corralejo (M10) and Huanimaro (M09) modules. Although, it can be 
concluded that a water market is a feasible mechanism for the aggregated Irrigation District 011; at module scale, those modules which export water have a loss in the net revenue, participating in the water market.

Table 7. Module net revenues with and without $50 \%$ shortage and water market (in US\$1000).

\begin{tabular}{ccccc}
\hline Irrigation Modules & Base Revenues & $\begin{array}{c}\text { Drought without } \\
\text { Market }\end{array}$ & $\begin{array}{c}\text { Drought with } \\
\text { Market }\end{array}$ & $\begin{array}{c}\text { Percent Change } \\
\text { (\%) }\end{array}$ \\
\hline M01 & 5683.95 & 3156.37 & 4241.49 & 34.38 \\
M02 & $18,174.14$ & $12,574.99$ & $13,660.20$ & 8.63 \\
M03 & 8724.04 & 6108.52 & 5879.39 & -3.75 \\
M04 & $18,557.21$ & $13,056.52$ & $13,637.40$ & 4.45 \\
M05 & $20,719.60$ & $14,966.36$ & $16,006.41$ & 6.95 \\
M06 & $20,652.89$ & $17,646.44$ & $16,381.27$ & -7.17 \\
M07 & $13,854.32$ & $11,302.13$ & $10,986.09$ & -2.80 \\
M08 & $17,191.99$ & $13,897.82$ & $13,312.13$ & -4.21 \\
M09 & 3369.44 & 2772.82 & 2630.73 & -5.12 \\
M10 & 1654.88 & 1425.20 & 1212.94 & -14.89 \\
M11 & 4836.17 & 4373.38 & 4322.70 & -1.16 \\
Total & $133,418.62$ & $101,280.55$ & $102,270.76$ & 0.98 \\
\hline
\end{tabular}

Source: Results of this research.

\section{Discussion}

The results showed a price elasticity of water demand between -0.33 and -0.66 , which is similar to other elasticities obtained in México [47] and in other countries [53,71]. The elasticity of water demand could be a limitation for pricing policies, as commented by Garrido A. and Calatrava J [7] of both cases Mexico and EU, but water elasticity to other factors such as environmental policies, commodities prices, and technological changes can have grater impacts to water demand.

Other authors have proved the demand price elasticity as a serious limitation; Exposito and Berbel [74] concluded that water pricing policy loses effectiveness in areas characterized by water scarcity and supply restrictions, as overexploited aquifers. Although success pricing policy cases exists, Rogers et al. [75] commented that integrated pricing from all sources should exist and be supplemented by other policies and indicators (environmental and social), discussed by other studies [16,54]. Providing a price for water would make the opportunity cost of water explicit to farmers, which could lead them to changes in selecting crops, and could incentivize the participation in the water market during drought.

The experience in other countries, reported by The World Bank and the OECD [76], showed that notwithstanding the inelasticity of water demand, this does not prevent water reduction in the total water use by a small price increasing, especially where water use is very large. But they comment that "water pricing would reduce withdrawals and applications but not necessarily water consumption". Pricing electricity as a policy to reduce groundwater overexploitation has failed in Guanajuato [40]; for this reason, other policies must be applied, as well as regulations and economic incentives; in order to achieve a sustainable use of groundwater, pricing water could be an effective policy for reducing groundwater overexploitation.

The water market model results in a total of $0.87 \%$ and $0.91 \%$ reductions in losses from drought for the $25 \%$ and $50 \%$ shortages, respectively. These figures are low compared to other research, which report loss reductions up to 30\% and 33\% [50,77] in California and Spain. But these are close to other results, in Pujol et al. (2016) [24], who report a total lose reduction up to $2.9 \%$. They concluded that, although the water market has low economic gain compared with the scenario without water market, this policy might guarantee an optimal reassignment of the resource as well as a positive social impact and the water management by the water administration. 
In the particular case of this research, the total reduction in loss for both scenarios could be a serious limitation, since the transaction costs were not considered due to lack of information. In other countries, high transaction costs in water markets, as in the Australian case, have demonstrated to be an impediment for an effective policy implementation [78].

Although the improvement is low, the water market reallocates water, which promotes efficiency and could make the farmers aware of the value of water. Formal water markets can reduce social conflicts and informal water markets that have grown in the last years; on the other hand, as proved in the model, undesired socio-economic consequences may result; small modules, which are mainly owned by small scale farms and "ejidos", would export big quantities of water to bigger modules, which land is owned by large scale producers, who cultivate high revenue crops, have higher yields, and use more irrigation technology.

Despite the fact a water market can make more efficient the use of water, a correct policy implementation must contemplate the socio-economic impacts mentioned above; in the model, a 50\% export capacity was considered, but if this capacity is increased, in both scenarios the total rate of exported water of small modules would have increased.

Water markets have proven to be a successful tool against drought in other countries such as United States, Spain, and Australia; Mexican water administrators and researchers can learn from their experience, especially on how they have adapted their legal and regulatory framework, in order to reach an efficient, equitable, and sustainable policy. Although in México the Water Law enable water titles transactions, in order to effectively apply this policy, the administrators need to take into account different aspects in addition to economic instruments, such as environmental and social aspects; moreover, a correct regularization of the water titles and strict monitoring of water pumped from wells.

Water governance is other aspect that must be considered for an effective policy application. The Lerma-Chapala Basin Committee, each year, assigns the volume of surface water that the Irrigation District can use over a span of a year; the committee has served as a joint dialogue for multiple surface water users, social organizations, and institutions. On the other hand, underground water is only regulated by CONAGUA; Aquifer Management Councils (COTAS) exist, but they have no legal authority to participate in granting concessions and serve only as a financial and technical support.

Notwithstanding, these councils could work in cooperation in CONAGUA, to achieve a regulated and monitored aquifer. The Water Law needs to adapt for these changes, together with the central government's support [79]. Furthermore, a coordination between the surface use water and ground water pumping should exist.

The administrators of the Irrigation District 011 and CONAGUA agreed with the need to raise the water rate, which is not covering the operation and maintenance of the system and does not reflect the value and viability conditions. Climate change and drought are topics that concern administrators, and they are willing to develop policies against their impacts. They have also expressed their concern to have a value of water and they consider that a pricing policy would promote an efficient use of the resource. The optimal rate scheme is under discussion; right now, it is by irrigated hectare, but they consider that a volumetric rate could be adequate; however, at the Irrigation District, water meters at parcel level do not exist, and CONAGUA have invested in metering instruments along the irrigation system, but they have been stolen, creating conflicts in future investments for metering tools.

This research presents various limitations and potential areas of improvement in the use of data, including non-differentiation of irrigation technologies, use of aggregate costs, and non-use of data from other inputs as they were not available in databases at the time of the research. Additionally, new ways of calibrating positive mathematical programming models have been developed, such as the use of exponential costs or the use of maximum entropy, for which will be required a reformulation of the model and a disaggregation of data. Finally, the exchange of water between users in a market is regulated by the National Water Law and its regulations, which could limit some of the transactions described in this research and requires further examination. 
Despite the limitations described, the results provide robust indication of the economic value of water in every module and in the irrigation district, for different drought scenarios. Likewise, they allowed us to evaluate the possibility of creating a water market with the conditions presented by the modules in the base year selected, as a mechanism to address drought. Based on these results, it will be possible to make recommendations on water pricing and management policies within the irrigation district.

In order to achieve a more rigorous incorporation of the mathematical programming model, future research should consider disaggregated costs, the use of supply elasticities, and a more detailed dataset to calculate crop production functions. To improve the analysis of the water market, transaction costs should be considered in the model, as well as the possibility of water being imported by the public water supply and industrial sectors, which will allow a more accurate analysis at basin level.

\section{Conclusions}

This research employs a deductive method for estimating the economic value of agricultural water in an irrigation district in the central Mexican high plains, composed of 11 modules. The economic feasibility of creating a water market under scarcity scenarios was assessed using minimum datasets.

The economic value of water obtained is higher than the rate currently paid by irrigation users, both for gravity irrigation water and water extracted from wells, in all scenarios considered. It is expected that increasing these rates to the estimated water valuation would promote a more efficient use of this in the long term. With this increase, users are expected to choose to plant crops with a greater economic value or lower water consumption, as demonstrated by changes in the optimal crop pattern.

The results show some economic gains from creating a water market in Irrigation District 011, under $25 \%$ and $50 \%$ shortage scenarios assuming free transaction of water rights. In both cases, the water market allows sowing a slightly larger area obtaining greater aggregate net income, derived from the transfer of water from those modules in which water has a low value to those where water has a greater value, depending on the shortage level caused by drought. By creating a market policy, water would be efficiently allocated in economic terms. In addition, water would be traded where a greater income is generated; and would make agriculture in the district more resilient to drought.

In order to implement these policies, there must be transparency and communication between authorities and users, the water market must operate flexibly in the face of different water availability scenarios, and there must be a consistent legal and administrative system that allows an effective regulation and governance by authorities.

The results of this research demonstrate the usefulness of the positive mathematical programming methodology with minimal input dataset requirements to valuate water and assess allocation policies. PMP is useful for modeling drought scenarios and water management policies, which can be applied in other Mexican irrigation districts and in other countries with irrigated agriculture and water scarcity.

Author Contributions: The study is part of a MSc. research conducted by Rodriguez-Flores. The paper is conducted as a joint effort of all authors. Conceptualization, J.M.R.-F., J.M.-A. and R.V.-A.; Formal analysis, J.M.-A., R.V.-A. and O.A.A.-C.; Investigation, J.M.R.-F.; Methodology, J.M.-A.; Resources, R.V.-A. and O.A.A.-C.; Supervision, O.A.A.-C. and R.C.G.-S.; Validation, R.V.-A., O.A.A.-C. and R.C.G.-S.; Writing-original draft, J.M.R.-F.; Writing一review \& editing, J.M.-A.

Funding: This research was funded by the National Council of Science and Technology of México (CONACYT).

Acknowledgments: The data used was provided by the Irrigation District 011 Office and the National Council of Water (CONAGUA) authorities. The authors would like to thank Alfredo Marmolejo, Chief Director of the Irrigation District 011 Limited Liability Association and Vertario Trejo, Chief Operations Officer of the ID011 (CONAGUA).

Conflicts of Interest: The authors declare no conflict of interest. 


\section{References}

1. CONAGUA; SEMARNAT. Atlas Del Agua En México 2016; CONAGUA, SEMARNAT: Mexico City, Mexico, 2016.

2. Scheierling, S.M.; Treguer, D.O.; Booker, J.F.; Decker, E. How to Assess Agricultural Water Productivity? Looking for Water in the Agricultural Productivity and Efficiency Literature; Water Global Practice Group and Agriculture Global Practice Group: Washington, DC, USA, 2014; p. 6982.

3. FAO. Afrontar La Escasez de Agua Un Marco de Acción Para La Agricultura y La Seguridad Alimentaria; FAO: Rome, Italy, 2013.

4. Ward, F. The economic value of water in agriculture: Concepts and policy applications. Water Policy 2002, 4, 423-446. [CrossRef]

5. Johansson, R. Pricing irrigation water: A review of theory and practice. Water Policy 2002, 4, $173-199$. [CrossRef]

6. Molle, F. Water scarcity, prices and quotas: A review of evidence on irrigation volumetric pricing. Irrig. Drain. Syst. 2009, 23, 43-58. [CrossRef]

7. Garrido, A.; Calatrava, J. Agricultural Water Pricing: EU and Mexico; OECD: Paris, France, 2010. [CrossRef]

8. Grafton, Q.; Libecap, G.; McGlennon, S.; Landry, C.; O’Brien, B.; O’Brien, B. An Integrated Assessment of Water Markets: A Cross-Country Comparison. Rev. Environ. Econ. Policy 2011, 5, 219-239. [CrossRef]

9. Palomo-Hierro, S.; Gómez-Limón, J.A.; Riesgo, L. Water Markets in Spain: Performance and Challenges. Water 2015, 7, 652-678. [CrossRef]

10. Chong, H.; Sunding, D. Water Markets and Trading. Annu. Resour. 2006, 31, 239-264. [CrossRef]

11. Loch, A.; Wheeler, S.; Bjornlund, H.; Beecham, S.; Edwards, J.; Zuo, A.; Shanahan, M. The Role of Water Markets in Climate Change Adaptation; National Climate Change Adaptation Research Facility: Gold Coast, Australia, 2013.

12. Howitt, R.E. Agricultural and Environmental Policy Models: Calibration, Estimation and Optimization; University of California: Davis, CA, USA, 2005; p. 207.

13. Young, R.A. Nonmarket Economic Valuation for Irrigation Water Policy Decisions: Some Methodological Issues. J. Contemp. Water Res. Educ. 2005, 131, 21-25. [CrossRef]

14. Tsur, Y. Economic Aspects of Irrigation Water Pricing. Can. Water Resour. J. 2005, 30, 31-46. [CrossRef]

15. Dudu, H.; Chumi, S. Economics of Irrigation Water Management: A Literature Survey with Focus on Partial and General Equilibrium Models; The World Bank: Washington, DC, USA, 2008.

16. Zhu, X.; Zhang, G.; Yuan, K.; Ling, H.; Xu, H. Evaluation of Agricultural Water Pricing in an Irrigation District Based on a Bayesian Network. Water 2018, 10, 768. [CrossRef]

17. Mesa-Jurado, M.A.; Martin-Ortega, J.; Ruto, E.; Berbel, J. The economic value of guaranteed water supply for irrigation under scarcity conditions. Agric. Water Manag. 2012, 113, 10-18. [CrossRef]

18. Sun, T.; Huang, Q.; Wang, J. Estimation of Irrigation Water Demand and Economic Returns of Water in Zhangye Basin. Water 2017, 10, 19. [CrossRef]

19. Booker, J.F.; Howitt, R.E.; Michelsen, A.M.; Young, R.A. Economics and the Modeling of Water Resources and Policies. Nat. Resour. Model. 2012, 25, 168-218. [CrossRef]

20. Harou, J.J.; Pulido-Velazquez, M.; Rosenberg, D.E.; Medellín-Azuara, J.; Lund, J.R.; Howitt, R.E. Hydro-economic models: Concepts, design, applications, and future prospects. J. Hydrol. 2009, 375, 627-643. [CrossRef]

21. Singh, A. Irrigation Planning and Management Through Optimization Modelling. Water Resour. Manag. 2014, 28, 1-14. [CrossRef]

22. Wang, Z.; Yang, J.; Deng, X.; Lan, X. Optimal Water Resources Allocation under the Constraint of Land Use in the Heihe River Basin of China. Sustainability 2015, 7, 1558-1575. [CrossRef]

23. Erfani, T.; Binions, O.; Harou, J.J. Simulating water markets with transaction costs. Water Resour. Res. 2014, 50, 4726-4745. [CrossRef] [PubMed]

24. Pujol, J.; Berbel, J.; De Cartagena, F.R.; Viaggi, D.; Raggi, M. Evaluation of markets for irrigation water in the internal river basins of Catalonia, Spain. Span. J. Agric. 2006, 4, 3-16. [CrossRef]

25. Garrido, A.; Calatrava, J. Modelling water markets under uncertain water supply. Eur. Agric. Econ. 2005, 32, 119-142. 
26. Grafton, R.Q.; Chu, H.L.; Stewardson, M.; Kompas, T. Optimal dynamic water allocation: Irrigation extractions and environmental tradeoffs in the Murray River, Australia. Water Resour. Res. 2011, 47, W00G08. [CrossRef]

27. CONAGUA. Información de concesiones del Registro Publico de Derechos del Agua (REPDA). Available online: https://www.gob.mx/conagua/acciones-y-programas/registro-publico-de-derechos-de-agua-repda55190 (accessed on 20 June 2018).

28. DOF (Diario Oficial de la Federacion). 4/01/2018, Acuerdo Por El Que Se Actualiza La Disponibilidad Media Anual de Agua Subterránea de Los 653 Acuíferos de Los Estados Unidos Mexicanos, Mismos Que Forman Parte de Las Regiones Hidrológico-Administrativas Que Se Indican; DOF: México City, México, 2018.

29. Escobar, B. La Cuenca Lerma-Chapala. El Agua de La Discordia. Gest. Polit. Publica 2006, 15, 369-391.

30. Wester, P. Shedding the Waters: Institutional Change and Water Control in the Lerma-Chapala Basin, Mexico; Water Resources Management: Wageningen, The Netherlands, 2008.

31. DOF (Diario Oficial de la Federacion). 08/04/2014, Dereto Por El Que Por Causas de Interés Público Se Suprimen Las Vedas Existentes En La Subregión Hidrológica Lerma-Chapala, y Se Establece Zona de Veda En Las 19 Cuencas Hidrológicas Que Comprende Dicha Subregión Hidrológica; DOF: México City, México, 2014.

32. Fernández-Durán, J.J.; Lloret, A. Consumo de Agua y Producto Interno Bruto En La Cuenca Lerma-Chapala. Tecnol. Ciencias Agua 2016, 7, 129-138.

33. Hansen, A.M.; van Afferden, M. The Lerma-Chapala Watershed; Hansen, A.M., van Afferden, M., Eds.; Springer US: Boston, MA, USA, 2001.

34. Reis, N. Coyotes, Concessions and Construction Companies: Illegal Water Markets and Legally Constructed Water Scarcity in Central Mexico. Water Altern. 2014, 7, 542-560.

35. SAGARPA-FAO. México: El Sector Agropecuario Ante El Desafío Del Cambio Climático; SAGARPA-FAO: Mexico City, Mexico, 2012.

36. Diagnostico Climatologico y Prospectiva Sobre Vulneravilidad Al Cambio Climatico En El Estado de Guanajuato; Instituto de Ecología del Estado de Guanajuato (IEE), SEMARNAT, INE, CCAUG: Salamanca, Mexico, 2011.

37. Government of the United States of Mexico. LAN, Ley de Aguas Nacionales. Last Updated/Ammended 24-03-2016 in the Offical Diary of the Federation (DOF); Government of the United States of Mexico: Mexico City, Mexico, 2016.

38. OECD Studies on Water. Water Resources Allocation: Sharing Risks and Opportunities; OECD Studies on Water; OECD Publishing: Paris, France, 2015. [CrossRef]

39. Pérez, H.M.B.; Ramirez, J.C.C.; Andrade, M.Á.G. El Banco de Agua: Una Propuesta Para Salvar El Lago de Chapala. Gest. Polit. Publica 2005, 14, 289-309.

40. Hoogesteger, J.; Wester, P. Regulating groundwater use: The challenges of policy implementation in Guanajuato, Central Mexico. Environ. Sci. Policy 2017, 77, 107-113. [CrossRef]

41. Comision Federal de Electricidad (CFE). Tarifa Nueve Cargo Unico. Available online: https://app.cfe.mx/ Aplicaciones/CCFE/Tarifas/TarifasCRECasa/Tarifas/AgricolaCargoUnico.aspx (accessed on 15 June 2018).

42. Scott, C.A.; Shah, T. Groundwater overdraft reduction through agricultural energy policy: Insights from India and Mexico. Int. J. Water Resour. Dev. 2004, 20, 149-164. [CrossRef]

43. Young, R.A. Measuring Economic Benefits for Water Investments and Policies; The World Bank: Washington, DC, USA, 1996; Volume 1. [CrossRef]

44. Florencio Cruz, V.; Valdivia Alcalá, R.; Scott, C.A. Productividad Del Agua En El Distrito de Riego 011, Alto Rio Lerma. Agrociencia 2002, 36, 483-493.

45. Norton, R.D.; Hazell, P.B. Mathematical Programming for Economic Analysis In Agriculture; Norton, R.D., Ed.; Macmillan: New York, NY, USA, 1986.

46. Howitt, R.E. Positive Mathematical Programming. Oxf. J. 1995, 77, 366-422. [CrossRef]

47. Medellin-Azuara, J.; Howitt, R.E.; Waller-Barrera, C.; Mendoza-Espinosa, L.G.; Lund, J.R.; Taylor, J.E. A Calibrated Agricultural Water Demand Model for Three Regions in Northern Baja California. Agrociencia 2009, 43, 83-96.

48. Gibbons, D.C. Economic Value of Water; Resources for the Future: Washington, DC, USA, 1986.

49. Young, R.A.; Loomis, J.B. Determining the Economic Value of Water, 2nd ed.; Taylor \& Francis: Didcot, UK, 2014.

50. Howitt, R.E.; Medellín-Azuara, J.; MacEwan, D.; Lund, J.R. Calibrating disaggregate economic models of agricultural production and water management. Environ. Model. Softw. 2012, 38, 244-258. [CrossRef] 
51. Franco-Crespo, C.; Viñas, J.M.S. The Impact of Pricing Policies on Irrigation Water for Agro-Food Farms in Ecuador. Sustainability 2017, 9, 1515. [CrossRef]

52. Cortignani, R.; Severini, S. Modeling farm-level adoption of deficit irrigation using Positive Mathematical Programming. Agric. Water Manag. 2009, 96, 1785-1791. [CrossRef]

53. Watto, M.A.; Mugera, A.W. Irrigation Water Demand and Implications for Groundwater Pricing in Pakistan. Water Policy 2016, 18, 565-585. [CrossRef]

54. Gallego-Ayala, J.; Gómez-Limón, J.A.; Arriaza, M. Irrigation water pricing instruments: A sustainability assessment. Span. J. Agric. 2011, 9, 981-999. [CrossRef]

55. Ponce, R.; Blanco, M.; Giupponi, C. Climate Change, Water Scarcity in Agriculture and the Country-Level Economic Impacts. A Multimarket Analysis; Universidad del Desarrollo: Concepción, Chile, 2014.

56. Torres MD, O.; Maneta, M.; Howitt, R.; Vosti, S.A.; Wallender, W.W.; Bassoi, L.H.; Rodrigues, L.N. Economic Impacts of Regional Water Scarcity in the São Francisco River Basin, Brazil: An Application of a Linked Hydro-Economic Model. Environ. Dev. Econ. 2012, 17, 227-248. [CrossRef]

57. Medellín-Azuara, J.; Harou, J.J.; Howitt, R.E. Estimating economic value of agricultural water under changing conditions and the effects of spatial aggregation. Sci. Total. Environ. 2010, 408, 5639-5648. [CrossRef] [PubMed]

58. Graveline, N.; Majone, B.; van Duinen, R.; Ansink, E. Hydro-Economic Modeling of Water Scarcity under Global Change: An Application to the Gállego River Basin (Spain). Reg. Environ. Chang. 2014, 14, 119-132. [CrossRef]

59. Heckelei, T.; Britz, W.; Zhang, Y. Positive Mathematical Programming Approaches-Recent Developments in Literature and Applied Modelling. Bio-Based Appl. Econ. 2012, 1, 109-124. [CrossRef]

60. Mérel, P.; Howitt, R. Theory and Application of Positive Mathematical Programming in Agriculture and the Environment. Annu. Econ. 2014, 6, 451-470. [CrossRef]

61. Wolff, H.; Heckelei, T. Estimation of constrained optimisation models for agricultural supply analysis based on generalised maximum entropy. Eur. Agric. Econ. 2003, 30, 27-50.

62. Howitt, R.E. A calibration method for agricultural economic production models. J. Agric. Econ. 1995, 46, 147-159. [CrossRef]

63. GAMS Development Corporation. General Algebraic Modeling System (GAMS) Release 25.1; GAMS Development Corporation: Washington, DC, USA, 2018.

64. CONAGUA. Costos de Producción Por Módulo 2014-Sistema Gerencial de Estadísticas Agrícolas e Hidrométricas, Jefatura Del Distrito de Riego 011, Alto Rio Lerma; Electronic File; CONAGUA: Celaya, Mexico, 2018.

65. CONAGUA. Informes de Producción Por Tenencia 2014-Jefatura Del Distrito de Riego 011, Alto Rio Lerma; Electronic File; CONAGUA: Celaya, Mexico, 2018.

66. CONAGUA. Plan de Riegos 2014-Jefatura Del Distrito de Riego 011, Alto Rio Lerma; Electronic File; CONAGUA: Celaya, Mexico, 2018.

67. CONAGUA. Informe Entregas de Aguas Mensuales 2006-Sociedad de Responsabilidad Limitada Del Distrito de Riego 011, Alto Rio Lerma; CD-ROM; CONAGUA: Irapuato, Mexico, 2018.

68. SAGARPA. Estadística de Producción Agrícola. Available online: http://infosiap.siap.gob.mx/gobmx/ datosAbiertos.php (accessed on 15 April 2018).

69. Secretaria de Economía. Precios de mercados agricolas. Available online: http://www.economia-sniim.gob. $\mathrm{mx} /$ (accessed on 20 May 2018).

70. McCarl, B.A. McCarl GAMS User Guide; GAMS Development Corporation: Fairfax, VA, USA, 2015; Volume 13. [CrossRef]

71. Scheierling, S.M.; Loomis, J.B.; Young, R.A. Irrigation water demand: A meta-analysis of price elasticities. Water Resour. Res. 2006, 42, W01411. [CrossRef]

72. Guzman-Soria, E.; Hernándes Martinez, J.; García-Salazar, J.A.; Rebollar-Rebollar, S.; de la Garza Carranza, M.T.; Hernandez-Soto, D. Consumo de Agua Subterránea En Guanajuato, México. Agrociencia 2009, 43, 749-761.

73. Marques, G.F.; Lund, J.R.; Howitt, R.E. Modeling irrigated agricultural production and water use decisions under water supply uncertainty. Water Resour. Res. 2005, 41, W08423. [CrossRef]

74. Expósito, A.; Berbel, J. Why Is Water Pricing Ineffective for Deficit Irrigation Schemes? A Case Study in Southern Spain. Water Resour. Manag. 2017, 31, 1047-1059. [CrossRef] 
75. Rogers, P. Water is an economic good: How to use prices to promote equity, efficiency, and sustainability. Water Policy 2002, 4, 1-17. [CrossRef]

76. OECD and The World Bank. Facilitating Policy Change towards Sustainable Water Use in Agriculture; OECD: Paris, France, 2018.

77. Montilla-López, N.M.; Gomez-Limon, J.A.; Gutiérrez-Martín, C. Sharing a river: Potential performance of a water bank for reallocating irrigation water. Agric. Water Manag. 2018, 200, 47-59. [CrossRef]

78. McCann, L.; Garrick, D. Transaction Costs and Policy Design for Water Markets. In Water Resources Allocation; Springer Nature: Basingstoke, UK, 2014; Volume 11, pp. 11-34.

79. Sandoval, R. A participatory approach to integrated aquifer management: The case of Guanajuato State, Mexico. Hydrogeol. J. 2004, 12, 6-13. [CrossRef]

(C) 2019 by the authors. Licensee MDPI, Basel, Switzerland. This article is an open access article distributed under the terms and conditions of the Creative Commons Attribution (CC BY) license (http://creativecommons.org/licenses/by/4.0/). 